DANTE'S THEOLOGY. 


\section{DANTE'S THEOLOGY.'}

By REv, PHILIP SCHAFF, DD., LL.D.,

Professoz of Church History, Union Theological Seminary, New York City.

The Divina Commedia, that "sacred poem"-

"To which both heaven and earth have set their hand,"

has an equal attraction for the poet, the historian, the philosopher, and the theologian. It is a mirror of mediæval Christianity and civilization, and resembles a Gothic cathedral which lays all sciences and arts under contribution and fills the mind with wonder and awe. It has justly been called "the mediæval miracle of song." No poem can be compared with it for general and abiding interest except the Book of Job, and Goethe's Faust.

Dante is emphatically a theological poet, and has always had a special charm for theologians of all schools and parties. He is the Poet among divines and the Divine among poets. As he stands between Homer and Virgil on the Parnassus, so does he also between St. Thomas Aquinas and St. Bonaventura before the altar of the holy mystery. His theology and his relation to modern Christianity and civilization have been the subject of considerable dispute. Roman Catholics, evangelical Protestants, and political Liberals have claimed him as their own. Three views may be distinguished.

I. He was an orthodox Catholic. This is held by the great majority of Dante-scholars, especially Giuliani, Ozanam, Artaud de Montor, Boissard, Philalethes, Wegele, Gietmann,

${ }^{1}$ In his unwritten address before the American Society of Church History, Dr. Schaff gave a brief survey of Dante's journey through the Inferno, Purgatorio, and Paradiso, and explained the spiritual and perpetual meaning of that "mystic, unfathomable song." He has elaborated two essays on the Life and Works of Dante, which are too long for this volume, but will appear in a book on Literatzure and Poetry (to be published by Charles Scribner's Sons, New York, r8go.) 
Hettinger. But the most orthodox Catholics cannot deny Dante's fearless opposition to the popes of his age, nor can they accept his politics.

2. He was a forerunner of Protestantism. Matthias Flacius the first Lutheran Church historian, numbers him among his four hundred and twenty "Witnesses of the Evangelical Truth" in the Dark Ages, i. e., among the Lutherans before Luther, as he regarded them, and quotes some passages from the Commedia and the book De Monarchia which bear on the corruptions of the Roman Church. Thirty years afterwards (1586) a French nobleman, François Perot de Mezières, endeavored to gain the Italians for the Reformation by means of the Commedia. Another Frenchman, Philippe de Mornay du Plessy Marly, the most accomplished and influential controversialist and diplomat among the Huguenots of his age, led Dante into the field against popery, in a work on the "Mystery of Iniquity" (I6II). The controversy has been renewed in our century by Goeschel and Karl Graul, who claim Dante as a Reformer before the Reformation. Some have even found, anagrammatically, the name of Luther (Lutero) in the Greyhound (Veltro) whom Dante prophesied as a future reformer, but by whom he undoubtedly meant his patron, Can Grande della Scala of Verona, the head of the Ghibelline party in Lombardy and vicar of the German Emperor Henry VII.

3. $\mathrm{He}$ was a heretic in disguise, and even a revolutionist and socialist, in league with widespread anti-papal and anticatholic societies for the overthrow of Church and State. $\mathrm{He}$ was a master of the symbolic language of the Templars, used for their destructive aims, a friend of the Albigenses, a Provençal mocker, a worshipper of classical heathenism, a pantheist, an infidel, a Voltaire in the fourteenth century. This strange theory was first proposed by Gabriele Rossetti, an Italian patriot, in an anti-catholic spirit, 1832 , and afterwards (I 854 ) in a modified form by Aroux, an orthodox catholic, and a translator of the Commedia.

The third theory must be dismissed as a radical misunderstanding and an ingenious absurdity. The first is essentially 
correct, but there is also an element of truth in the second theory. Dante was a sincere and earnest Catholic of the medirval, but not of the modern ultramontane type. $\mathrm{He}$ belonged to the party of progress which demanded a reformaation of the Church, especially of the papacy; and in this respect we may regard him as a prophet of a purer form of Christianity.

We can, of course, only judge from what he actually believed and taught, not from what he might have believed in another age and under other conditions. But judging him from the spirit of his works he would have advocated the cause of truth and righteousness, of progress and moral reform, in any subsequent age.

He would have thoroughly sympathized with Savonarola, the stern monk, prophet, and reform preacher, in opposition to the frivolity of Florence, and the wickedness of Pope Alexander VI., who demanded his execution at the stake. He would have gone half-way with Luther, in his war against the shameful traffic in indulgences, and the corruptions of the papacy, but no further. In the year I 870 he would have opposed, with Döllinger and the Old Catholics, the two Vatican dogmas of papal infallibility aud papal absolutism. In politics he, the Italian of Italians, and the idol of Italian patriots, would have hailed the national movement for the union and independence of Italy, the destruction of the temporal power of the papacy, and the separation of Church and State, or the triumph of Cavour's principle of a Free Church in a Free State.

But we must not identify him with Protestantism in any of its systems of doctrine or Church polity. He probably even to-day would look forward to an ideal Catholicism of the future and prophesy the coming of another Veltro and $D u x$, who would restore a universal church and a universal empire in friendly independence and confederation for the spiritual and temporal welfare of mankind.

We cannot find in his writings any distinctively Protestant principles, such as the supremacy of the Scriptures over traditions, justification by faith alone, or the general 
priesthood of the laity. He is full of Scripture facts and Scripture doctrines, but throughout assumes that the teaching of the Church is in harmony with them; he believes in salvation by the grace of God and the atoning sacrifice of Christ, but demands good works and crowns them with reward; he teaches the divine origin and independence of the State, but expects the German emperor to be in communion with the Roman Church. In all essential doctrines which distinguish the Protestant from the Roman Catholic system he stands on the Roman Catholic side.

The same may be said of Savonarola, who has so often been misrepresented as a forerunner of Luther.

Dante is the poet of medireval Catholicism. His poetry reflects the theology of St. Thomas Aquinas and St. Bernard, that is, orthodox scholasticism and orthodox mysticism combined. The Commedia is a poetic transfiguration of mediæval theology and piety. He worked into it all the subtleties of scholastic speculation and all the warmth of mystic devotion to the very height of the beatific vision. He is a strong believer in the fundamental doctrines of the Trinity and Incarnation and all the articles of the œcumenical faith from creation to life everlasting. He clothes these truths in the shining garb of poetic beauty, and impresses them all the more deeply on the mind and heart. To a devout student the Divina Commedia is a powerful sermon accompanied by solemn organ music. Neither Milton, nor Klopstock, nor any other poet, Catholic or Protestant, can equal him in the poetic vindication and glorification of our common Christian faith.

In connection with this faith, Dante held also those mediaval doctrines which the Protestant Reformers, wisely or unwisely, rejected on account of their abuse, as the doctrines of Purgatory, the worship of saints, and the divine foundation of the papacy. Purgatory with its expiatory penances is one of the three divisions of his poem. The intercession of the saints in behalf of the living and the petitions of the living for that intercession run through the whole, and culminate in that wonderful prayer of St. Bernard 
to the holy Virgin Mother who is enthroned in Paradise as the Queen of Saints. He assumes throughout the closest communion between the militant and triumphant Church. Beatrice, Lucia, and Matilda are interested in his salvation and act under the inspiration of Mary. But as a follower of St. Bernard, he must have disapproved of the belief in her immaculate conception which then began to be advocated in the form of a special festival in France. He peoples heaven with orthodox saints, and excludes from it all impurity and heresy, and even all the unbaptized. He puts heretics in the sixth circle of the Inferno. He believes in the supremacy of Peter as the prince of the Apostles and founder of the Roman Church, who "keeps the keys," and examines and instructs him in the faith. He regards the Pope as Peter's successor and as the vicar of Christ. He knows only one Church, and condemns schism even more than heresy.

But here his connection with the Roman Catholic Church stops. It remains for us to consider his reformatory or Protestant element, if we may so call it.

\section{DANTE'S RELATION TO THE PAPACY AND THE REFORMATION.}

Dante is a most earnest and consistent advocate of a moral (not doctrinal) reformation in Church and State, especially of the papacy. He urges and predicts such a reformation in the head and the members again and again in all parts of his poem and in a variety of images. The very last words of his beloved Beatrice in Paradise are a condemnation of the Popes Boniface VIII. and Clement V., who shall be thrust down

\section{"Where Simon Magus is for his deserts."}

The key to his position is his prediction of the Greyhound (Veltro) and Leader (Dux), who should bring about such a reformation, and the political theory of his book on the Empire (De Monarchia), which was condemned by the Council of Trent. 
He treats the popes with the same stern impartiality as emperors, kings, and private persons, according to their moral merits. He respects the office, but condemns those who disgraced it, in such a fearless manner as would not be tolerated in the Roman Church of the present day. He mentions indeed several popes and cardinals among the blessed in heaven, as Gregory I. and Agapetus, but none of them is assigned so high a position as the great doctors of the Church and founders of monastic orders. He ignores Gregory VII., the greatest of the popes, probably because of his quarrel with the emperor. Innocent III. is barely mentioned. He met two popes among the penitents in Purgatory, namely, Adrian V. who sits among the avaricious in the fifth circle, but was pope only thirty-nine days (d. 1276), and Martin IV., who suffers among the gluttons, because his fondness for eels from the lake of Bolsena in the Papal States and the vernaccia wine, brought his life to a sudden close (I285). He saw a multitude of avaricious popes and cardinals in the fourth circle of Hell, which is guarded by Plutus as their jailer. He condemns a heretical pope, Anastasius II. (496). He is most severe on the simoniacal popes who are already, or will soon be, tormented in the eighth circle, notably Nicholas III. (d. I28I), Boniface VIII. (d. I3O3), and Clement V. (d. I3I4). The last two were still living when the Commedia was begun ( 1300 ), but Nicholas, with the foresight of disembodied spirits, knew that they were coming, and wondered only that they should come so soon and not tarry longer with their golden idols on earth.

The pope whom he most severely condemns and pursues a dozen times in all parts of his poem with fiery indignation and almost personal animosity, is Pope Boniface VIII. $\mathrm{He}$ regarded him as the chief author of his exile and all his misfortune, and as the worst of Simoniacs.

Boniface was a man of great learning, ability, and energy, but violent, cruel, ambitious, avaricious, and utterly unscrupulous. He scared the humble Colestin V. into a resignation, which was never before heard of in the history 
of the papacy, shut him up in a castle, bought the papal crown, created two of his very young nephews cardinals, appointed twenty bishops and archbishops from among his relatives and friends, and left them enormous sums of money. He made war upon the powerful family of the Colonnas and confiscated their vast possessions. He introduced the first papal jubilee with its abuses in the very year in which Dante began the Commedia. He carried the system of papal absolutism to the utmost extreme of audacity and pretension, and claimed in the bulla Unam Sanctam (1302) the highest temporal as well as ecclesiastical power on earth. A commission of investigation after his death, composed of Italians and Frenchmen well acquainted with him, charged him with the worst of crimes and even with infidelity. His haughty reign ended in humiliation, insult, and grief,- the opposite of the scene at Canossa. The public opinion of his contemporaries is expressed in the sentence: "He entered like a fox, he reigned like a lion, he died like a dog."

Dante and Boniface were political, ecclesiastical, and moral antipodes, but the poor exile triumphed over the mighty pope in the judgment of posterity. Dante called his antagonist the prince of modern Pharisees, a usurper of the papal chair, who bought and then abused the Church, and turned the cemetery of St. Peter, the Vatican Hill, into a common sewer of corruption.

Nevertheless he justly condemns with the same impartiality Philip the Fair of France, that "modern Pilate," for his cruel treatment of the aged pope at Anagni. He distinguished between the chair of Peter and "him who sits there and degenerates."

Dante was an ideal imperialist in direct opposition to the papal absolutism of Boniface. He believed in the unity of empire with two independent heads in amicable relation: the Roman pope as the spiritual ruler, the German Roman emperor as the secular ruler. Church and State are both divine institutions, the one for the eternal, the other for the temporal welfare of mankind. $\mathrm{He}$ borrowed his theory 
from the ante-Nicene period, but substituted a Christian for a heathen emperor. We may say that he anticipated the American theory of a friendly separation of Church and State, yet with this important difference, that he had in mind one Catholic Church instead of a number of denominations, and one Roman empire instead of a federal republic. The two powers should remain separate and distinct. A mixture of the two and a supremacy of one over the other (either in the form of the papal theocracy, or in the form of cæsaro-papacy) is a source of evil, of friction and war. There are two suns which give light to the world, the pope and the emperor. The State must not be degraded to a mere moon that borrows her light from the one sun, as is done in the Hildebrandian system.

\footnotetext{
"Rome, that reformed the world, accustomed was Two suns to have, which one road and the other, Of God and of the world, made manifest. One has the other quenched, and to the crosier The sword is joined, and ill beseemeth it That by main force one with the other go, Because, being joined, one feareth not the other."
}

Dante derived with the common opinion of the Middle Ages the temporal power of the pope from the fictitious donation of Constantine to Sylvester I., and repeatedly alludes to this fatal gift, which was well meant but "bore bad fruit."

\section{"Ah, Constantine! of how much woe was mother, Not thy conversion, but that marriage-dower Which the first wealthy Father took from thee !"}

He believed that the gift, if ever made, was unlawful, although it is incorporated in the canon law (the Decretum Gratiani). How would he have rejoiced if he could have seen the book of the Roman critic and humanist Laurentius Valla (Lorenzo della Valle, d. I457), who proved beyond contradiction that the donation of Constantine was nothing but a hierarchical fable. 
The principal evil which resulted from the temporal power of the pope and his connection with all the political quarrels and intrigues of the age, was simony, or the sin of Simon Magus, who wished to buy the Holy Ghost for lucrative purposes and incurred the fearful rebuke of St. Peter. "Thy silver perish with thee, because thou hast thought to obtain the gift of God with money. Thou hast neither part nor lot in this matter: for thy heart is not right before God. Repent therefore of this thy wickedness, and pray the Lord, if perhaps the thought of thy heart shall be forgiven thee. For I see that thou art in the gall of bitterness and in the bond of iniquity" (Acts viii. : 20-23). This passage is the text of Dante's invectives against the popes who made themselves guilty of the same sin and incurred double guilt on account of their exalted position as successors of St. Peter, and the incalculable influence of their bad example upon clergy, monks, and laity. It is notorious that many popes made merchandise of holy things, bought the papal crown, sold cardinals' hats and bishops' mitres, and perverted the property of the Church for the enrichment of their nephews and other members of their families. Nearly all the rich palaces of Roman nobles, with their picture galleries and treasures of art, owe their origin to papal nepotism. The worst period of the papacy was that of the so-called pornocracy in the tenth and eleventh centuries, which cannot be mentioned without humiliation and shame. It was then that the German emperors had to interfere and to depose those wicked popes, the paramours and bastards of some bold, bad Roman women. Henry VII., at the synod of Sutri (I046), deposed three rival popes, all simonists, and elected the worthy Bishop Bruno of Toul in their place (1048), as Leo IX., the first reforming pope under the direction of Hildebrand, who himself succeeded to the papal chair as Gregory VII. (IO73), and made war upon simony, but as well also upon sacerdotal marriage, and the power of the emperor. With all his zeal against simony, Gregory could not prevent his successors from relapsing into the same $\sin$. 
Dante condemns the simonists to the eighth circle of Hell, where they are turned upside down with their heads in a narrow hole and their feet and legs standing out and burning-a fit punishment for perverting the proper order of things by putting the material above the spiritual, and money above religion. The greatest sufferers in this pit are the simoniacal popes. The corruption of the Roman court contaminated the higher and lower clergy and the whole Church.

Dante looked to Germany for a reformation of the Church and a restoration of the Empire, but he was doomed to disappointment in the hope he set on Henry VII., and Can Grande of Verona, his vicar in Lombardy. In the meantime, after the death of Boniface, the papacy had been transferred to Avignon, and became subservient to the French monarchs. Then followed the scandalous papal schism, the reformatory councils, the restoration and renewed corruption of the papal power. At last the reformation came from Germany, but not from an emperor, and in a much more radical form than the poet dreamed of.

\section{DANTE AND THE JOACHIMITES.}

Dante stood not alone in his attitude to the papacy. There runs through all the Middle Ages a protest against the abuses in the Church and a desire for a reformation which grew stronger and stronger and ultimately culminated in the mighty religious revolution of the sixteenth century.

Before him and during his lifetime there was a considerable commotion in the Franciscan order with which he was in sympathy. Tradition connects him with this order. He was buried in the Franciscan church at Ravenna. His daughter Beatrice was a nun in a Franciscan convent of that city. He fully appreciated the monastic principle of apostolic poverty, and considered wealth and temporal power a curse to the clergy. He puts into the mouth of Thomas Aquinas, who was a Dominican, a high eulogy of St. Francis of Assisi ; while Bonaventura, a Franciscan, in 
the spirit of true brotherhood, without envy and jealousy, celebrates the life and deeds of St. Dominic. He assigns one of the uppermost places in the Rose of the Blessed to St. Francis, the most childlike, the most amiable, and the most poetic monk of the Middle Ages, the sympathizing friend of all God's creatures, whose highest aim and crowning glory was transformation into the image of the Saviour, who married Christ's poverty and dying left the care of this his " lady-love" (la sua donna piu cara) to every one of his disciples. Dante, who was probably familiar with Bonaventura's life of the saint, thus tersely describes his character:

\footnotetext{
“ On the rough rock 'twixt Tiber's and Arno's plain, From Christ received he the last seal's impress, Which he two years did in his limbs sustain.
}

When it pleased Him, who chose him thus to bless To lead him up the high reward to share Which he had merited by lowliness,

Then to his brothers, each as rightful heir, He gave in charge his lady-love most dear, And bade them love her with a steadfast care."

At the same time he complains of the departure of the Franciscans from the apostolic simplicity of their founder, and makes like complaint of the degeneracy of the Dominican order. He sympathized with the puritanical or spiritual party of the Joachimites, and with the reform movement which agitated the Franciscan order from the middle of the thirteenth century. He esteemed Joachim of Flore, or Fiore, who gave the first impulse to the movement, as a true prophet and assigned him a high place in Paradise with Ralanus Maurus, Dominic, Bonaventura, Chrysostom, and Arspelm.

" Here is Rabanus, and beside me here Shines the Calabrian Abbot Joachim, He with the spirit of prophecy endowed." 
Joachim was a prophet in the same sense as Dante was a prophet. He roused the conscience, he reproved wickedness, he predicted a better future, like the Hebrew prophets. A brief notice of this remarkable man and his school may not be out of place here. For fuller information about him and "the Everlasting Gospel" so called, I may refer to Wadding, Neander, Döllinger, Engelhardt, Hahn, Renan, Preger, Reuter, and the documents recently published by Denifle and Ehrle in their Archio für Litteratur- und Kirchengeschichte des Mittelalters (1885).

Joachim was abbot of a Cistercian convent at Flore, or Fiore, in Calabria, an older contemporary of St. Francis of Assisi (Renan calls him his Baptist), and like him an enthusiast for entire conformity to Christ in spirit and outward condition. He made a pilgrimage to the Holy Land, fasted forty days on Mount Sinai, led a life of self-denial and devotion to his fellow-men, studied with special zeal the prophetic portions of the Scriptures, opposed the worldliness and earthly possessions, simony, nepotism, and avarice of the clergy, and predicted a reformation. He died about 1202. He was revered by the people as a wonder-working prophet and saint. Neander says of him: "Grief over the corruption of the Church, longing desire for better times, profound Christian feeling, a meditative mind, and a glowing imagination, such are the peculiar characteristics of his spirit and of his writings."

Joachim wrote three works: "The Harmony of the Old and New Testament"; "Exposition of the Apocalypse"; "Psalter of Ten Chords." To the last are attached two hymns of Paradise, the second of which was, as Renan conjectures, one of the sources of Dante's Commedia. Several other works of uncertain authorship, especially commentaries on Isaiah and Jeremiah, were also ascribed to him.

He wished to be orthodox and remained in the communion of the Catholic Church, but his apocalyptic opinions could easily lead astray and be utilized for heretical purposes. After his death he was condemned by the Fourth Lateran Council (1215) for tritheism. He gave great offence by his 
attacks on the papacy and his prediction of "The Everlasting Gospel."

An older contemporary, St. Hildegard, abbess of the Rupert convent near Bingen on the Rhine (b. 1098, d. I 197), took a similar position on the church question, and was generally revered as a prophetess. Pope Eugene III. and St. Bernard of Clairvaux, while preaching the second crusade in Germany, recognized her divine mission, and persons of all ranks flocked to her for advice, intercession, consolation, and light on the future.

Joachim attacked as severely as Dante the corruption of the papacy of his time, although it was better represented in the early than in the latter part of the thirteenth century. He, too, traced the decay of morals and discipline to the temporal power and the love of money, which is "a root of all kinds of evil" (I Tim. vi.: IO). He complains of the exactions of the Roman curia. "The whole world is polluted with this evil. There is no city nor village where the Church does not push her benefices, collect her revenues. Everywhere she will have prebends, endless incomes. $\mathrm{O}$ God, how long dost thou delay to avenge the blood of the innocent which cries to thee from beneath the altar of the Roman capitol!" He condemns indulgences dispensed from Rome, and rebukes the proud and carnal cardinals and bishops who seek their own instead of the things of Christ. $\mathrm{He}$ often compares the Roman Church with the Babylon and the harlot of the Apocalypse, who commits fornication with the kings of the earth, and he predicts that the last and worst Antichrist will sit in the temple of God and the chair of Peter, and exalt himself above all that is called God. $\mathrm{He}$ agreed with Hildegard in announcing a terrible judgment and consequent purification and transformation of the Church and the papacy.

He divided the history of the world into three periods, which correspond to the persons of the Holy Trinity, the three leading Apostles-Peter, Paul, and John, and the three Christian graces-faith, hope, love. The period of the Father extends from the creation to the incarnation; Vol II -5 
the period of the Son to the year 1260; the period of the Holy Spirit to the end of the world. The first period is the period of the laity, the second that of the clergy, the third that of the spiritual monks under a papa angelicus. The first was ruled by the letter of the Old Testament; the second by the letter of the New Testament; the third will be ruled by the spirit of the New Testament, i. e., the spiritual understanding of the Gospel of Christ (spirituale evangelium Christi, spiritualis intelligentia Novi Testamenti). This is "The Everlasting Gospel," to be proclaimed by the angel in the Apocalypse (Rev. xiv.: 6). It is not a written book, but a donum Spiritus Sancti, a donum contemplationis, and the order which is to proclaim it, is an ecclesia contemplativa, a populus spiritualis.

The last period is the period of love represented by the beloved disciple, the period of peace, the Sabbath which remains for the people of God. It will be preceded by a terrible conflict with the concentrated power of Antichrist in its last and most powerful form. Then will be fulfilled the prophecy of Isaiah (xiii. : 9 sqq.), "when the day of Jehovah cometh with wrath and fierce anger to make the land a desolation and to destroy the sinners thereof, when the sun shall be darkened, and the moon shall not shine."

The three periods are also subdivided into seven subperiods, corresponding to the days of creation and the Sabbath of rest.

These views are more fully developed in the doubtful, than in the three genuine, writings of Joachim, and are involved in mystical fog.

The views of Joachim were adopted, enlarged, and exaggerated after his death by the Joachimites, a branch of the Franciscans, who opposed the prevailing laxity which had crept into the order, and who insisted on the severe rule of the founder. They were called Spirituals (Spirituales, Zelatores, Fraticelli). They indulged in ascetic extravagances and apocalyptic fancies, vehemently opposed the worldliness of the clergy and monks, and became more and more anti- 
papal and anti-churchly. Their war cry was "The Everlasting Gospel," which was to reform the Church and to convert the world.

Gerard, or Gherardino, of Borgo-San Donnino, a Franciscan monk, published at Paris, in 1254 , a popular epitome of Joachim's prophetic and apocalyptic writings, with an Introduction (Introductorius), under the title "The Everlasting Gospel," and announced the near advent of the Era of the Holy Spirit, which would abrogate the economy of the Son or the New Testament, as the economy of the Son had abrogated the economy of the Father or the Old Testament. By the Everlasting Gospel he meant the three chief works of Joachim, which were to take the place of the New Testament, and to be the canon of the dispensation of the Holy Spirit.

The publication excited a great commotion in the University of Paris and throughout the Church. Pope Alexander IV. appointed a Commission of investigation at Anagni, where he then resided. The result was the condemnation of "The Everlasting Gospel" in I255. Gherardino refused to recant, and was condemned to prison for life. He died there after eighteen years. The failure of the prophecy destroyed its effect after I 260 more effectually than the papal anathema. The expectations of the people were raised to the highest pitch in November of that year by a procession of the Flagellants of Perugia through Italy, but the year passed without ushering in the new era.

But the spirit of Joachim and Gerard revived in the party of the Spirituals and their successors, the Fraticelli. Their prophecies were renewed in modified forms, especially by Peter John de Oliva, who was styled Dr. Columbinus (the columba, or dove, being the symbol of the party, and of the Holy Spirit), and were published in a mystic commentary on the mysteries of the Apocalypse about 1290 . History was now divided into seven periods. The sixth period was dated from St. Francis of Assisi (b. I182), and extended to the time when the temporal power of the papacy, and with it 
the general corruption of the world, would reach its height and hasten the Divine judgment on the carnal Church. Then would appear the true spiritual Church of the Holy Spirit, free from the poison of earthly possessions, and would convert the Jews and Gentiles.

From year to year the Spirituals waited for the advent of the seventh period, but waited in vain. They led a pure and austere life, according to the strict rule of their founder. They declined to recognize any pope since John XXII. (1316-1324), and were fearfully persecuted for more than a hundred years. The bones of de Oliva were dug up and burnt, and his writings were prohibited until Sixtus IV. (I47I-I484), himself a Minorite, ordered a new investigation, which declared them orthodox.

The persecutions heightened the anti-papal spirit of the party, and matured the opinion that the papal chair was or might become for a season the very seat of Antichrist in the temple of God. This opinion was confirmed under Boniface VIII. by his audacious claim of supremacy over the whole world, his tyranny and immorality. It found expression in the writings of Giacopóne da Todi, of the order of the Minorites, the author of the Stabat Mater, and in the Commedia of Dante, his younger contemporary. Giacopóne was excommunicated and imprisoned by Boniface, but pronounced blessed by posterity. Dante was exiled by the Guelf government of Florence, under the influence of the same pope, but his exile gave the world the Divina Commedia.

Dante kept aloof from the ascetic extravagancies and apocalyptic fancies of the Joachimites and Spirituals. He had too much respect for Thomas Aquinas and Bonaventura, too much knowledge of theology, and too much taste for art to fall into such extremes. Besides, he had political aspirations which looked towards the restoration of the German Roman empire. But he agreed with the Joachimites in their warfare against the corrupt papacy of Boniface VIII., which he calls "a shameless whore firm as a rock seated on a mountain high," and in their zeal for a reformation of the Church in the head and members. 
DANTE AND SCHELLING. THE THREE AGES OF CHURCH HISTORY.

In the confused rubbish of the prophetic and pseudo-prophetic writings of Joachim di Fiore, there are not a few grains of gold and fruitful germs of truth. His division of three ages of history corresponding to the three persons of the Trinity, and the three leading Apostles, is one of these fruitful germs.

A modern German philosopher, who was a profound student of Dante, has independently arrived at a somewhat similar, though far superior construction of the history of Christianity. I refer to the concluding chapters of Schelling's Lectures on the Philosophy of Revelation, which were delivered at the University of Berlin, in 1842, but not published in an authentic form till 1858 . I heard his lectures, and learned from Schelling in a most interesting interview a few days before his death (which occured at Ragatz, Switzerland, Aug. 20, I854), that he derived great comfort from his theory of the three ages of the Church, but would supplement it by making room for the Apostle James, as the typical representative of the Oriental Church.

Schelling starts from the fact that Christ elected three favorite disciples-Peter, James, and John-to whom he gave new names (Rock, and Sons of Thunder), and whom he made sole witnesses of some of the most important events in his life. They correspond to Moses, the lawgiver; Elijah, the fiery prophet; and John the Baptist, who concluded the Old Dispensation by pointing to Christ.

Peter is the fundamental Apostle, the rock on which the Church was built, the Apostle of the Father, the Apostle of authority, the Apostle of law and stability, the type of Catholicism.

But the foundation of a building is only the beginning, and is followed by a succession, by a middle and end. These are represented by James and John, or rather by Paul and John. James died early, before he could fully develop his mission, and his place was filled by Paul, whom the Lord 
had called before the martyrdom of James, and who is in the earliest seals of the popes associated with Peter as joint founder of the Roman Church.

Paul is the Elijah of the Church, who burst forth like a fire, and whose word burns like a torch. He is the Apostle of God the Son. He built on the foundation of Peter, yet independently, and even in opposition to him; for it is by contrasts ( $\delta i \dot{\varepsilon} v \alpha v \tau i c o v$ ), not by uniformity, that the Spirit of God brings about the greatest results. He insists (in the Galatians) on his direct call by Christ, not by or through men, and at Antioch he openly withstood Peter and the

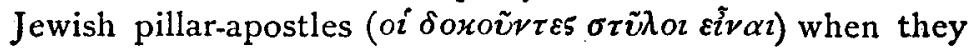
demanded the circumcision of the Gentile Christians, and their subjection to the bondage of the law. Paul represents the principle of independence, motion, development, and freedom; he is the type of the Protestant Reformation, that revolt long prepared against the exclusive and tyrannical authority of Peter.

Whatever may be said against the Roman Church is foreshadowed in Peter, and is not concealed in the Gospels, least in that of Mark (which is Peter's Gospel). $\mathrm{He}$, and he alone among the Apostles, took the sword, which is inseparable from an earthly kingdom, and the Roman Church wielded the sword, especially in the thirteenth century, against the heretics so-called, not only the New-Manichæans and Albigenses, but also against the Spirituals among the Franciscans, who perished in the flames of the stake by the thousands, and could find refuge only with the German emperor, Louis the Bavarian. It was among these that the opinion first arose that the pope was the veritable Antichrist and the beast of the Apocalypse. The same Peter, who was called the Rock of the Church, was soon afterwards called a Satan by our Saviour when he presumed to turn his Master away from the path of the cross. In the former character he was to be guided by Divine wisdom and power, in the latter he followed the instinct of worldly prudence. But Christ says: "If any man would come after me, let him deny himself, and take up his cross daily, and follow me." (Luke ix., 23.) The 
three folddenial of Peter has likewise a typical significance. The Roman Church has denied Christ in three ways : first, by striving after political power, then by using the political power as executioner of her bloody decrees, and last by yielding herself as an instrument to the secular arm. But as Christ intrusted the same Peter who had thrice denied him, thrice with the feeding of his flock, so the Roman Church, in whose bosom so many holy members have uttered sighs and complaints over her corruptions, has not ceased to be a Church of Christ, and to hold fast to the foundation of the faith. Perhaps the time is not far distant when she will, with Peter, weep bitterly over her denial.

John is the Apostle of the Holy Spirit, the Apostle of the Future, the Apostle of Love, and represents the New Jerusalem from heaven, the truly catholic, ideal Church of the union of Catholicism and Protestantism. He alone speaks of the Spirit whom the Son will send from the Father, who proceeds from the Father, and who will guide the Church into the whole and perfect truth. His position is indicated in the mysterious prediction of Christ to Peter concerning John: "If I will that he tarry till I come, what is that to thee?" (John xxi., 22.) This was at an early time misunderstood to indicate that John was not to die, but the real meaning is that his mission would begin with the second advent, that is, in the last age of the Church. It has no reference to the existence of John, but to his work, which can only be accomplished after the exclusiveness of Peter is done away with, and the Church arrives at the unity of the one flock and one Shepherd. (John x., I6.)

The Church of St. Lateran in Rome has the first rank in the Catholic world, as the Latin inscription says: "Sacrosancta Lateranensis ecclesia, omnium urbis et orbis ecclesiarum mater et caput." The splendid temple of St. Peter, which was the proximate occasion for the Reformation, stands in the centre of the city of Rome. The Church of St. Paul, which burned down under Pius VII., and is not yet quite rebuilt, is outside of the walls. At some future time a church will be built for all three Apostles-a true pantheon of Church History. 
This is a summary of Schelling's philosophy of Church History. It is, like all philosophical constructions which anticipate the future known only to God, more or less fanciful; but it is certainly grand and ingenious and involves a truth, which illuminates the past and gives hope for the future. It impresses itself indelibly upon the mind. I have it from the lips of such historians as the evangelical Neander and the catholic Döllinger, that they were in sympathy with it. The three chief Apostles and their work, the Jewish Christianity of Peter, the Gentile Christianity of Paul, the temporary collision of the two, and the final consolidation of both branches by John-anticipate and foreshadow the past and future development of Christ's kingdom on earth.

Dante likewise recognizes three typical Apostles who represent the three Christian graces, but he adheres to the original trio of Christ's first selection, and omits the Apostle Paul. He regards Peter as the Apostle of Faith, James the Elder (John's brother) as the Apostle of Hope, and John as the Apostle of Love. In Paradise he places Peter, as the keeper of the keys of the glorified Church, and John, as the seer, of "the beautiful bride who with the spear and with the nails was won," next to the Queen of Paradise in the mystic Rose of the Blessed. He sees John (with an allusion to the legend of his sleep till the second advent) in the chariot of the Church as

\section{"An aged man alone \\ Walking in sleep with countenance acute."}

The difference as well as the harmony in the Catholic and Protestant estimate of the Apostles is characteristic. A Protestant would subordinate James to Paul, and co-ordinate Peter and Paul as Apostles of Faith, and joint Founders of the Church, the one among the Jews, the other among the Gentiles. Paul was not one of the Twelve, and does not fit into the regular succession, but he is of equal power and authority with them, and as to the abundance of labors he surpassed them all. He was soon thrown into the background in the early Church, as a sort of holy outsider and 
dangerous innovator, and was never thoroughly appreciated till the time of the Reformation. Even such fathers as Origen, Chrysostom, and Jerome could not conceive it possible that he should have so boldly and sharply rebuked the older Apostle Peter at Antioch, and hence they perverted the scene into a theatrical farce or substituted an imaginary Peter for the historical Peter. Nor does the papal Church, in her official denunciations of Bible Societies, forget to quote Peter's words about the difficult matters in Paul's Epistles, and about the danger of "private interpretation" of the Scriptures.

But Joachim, Dante, and Schelling agree in the hopeful outlook toward a higher and purer age of the Church, and connect it with the name of the beloved Disciple, the bosom friend of Jesus, the seer of the new heavens and the new earth, the apostolic forerunner of an age of love, concord, and peace. 